\title{
Leder til temanummer Fremtidens skole
}

Tema for dette nummeret av Nordisk tidsskrift for pedagogikk og kritikk er Fremtidens skole: Hvilken fremtid har skolen? Hva er en skole for fremtiden? Bakgrunnen for temanummeret er de store endringer i den nordiske skolekulturen som pågår akkurat nå. Dette er endringer som inviterer til kritiske analyser og alternative synspunkter.

Nordisk tidsskrift for pedagogikk og kritikk inviterte nordiske forskere til å delta i samtalen om fremtidens skole. Vi ønsker å være en arena der også utdannelsens normative aspekt belyses og diskuteres. At det nå settes i gang en debatt om de normative sidene ved skole og utdanning, kan synes unødvendig eller betimelig, alt etter hvem man spør.

Flere utdanningsforskere har de siste årene pekt på at what works? har vært det styrende spørsmålet i diskusjoner om skole og utdanning, både blant forskere og politikere. Fokus har vært på å skaffe empirisk data for å begrunne hvilke undervisningsmetoder som virker - virker i den forstand at de mest mulig effektivt bidrar til at elevene i skolen oppnår stadig bedre læringsresultater. Dette fokuset har blant annet resultert i opprettelsen av Dansk Clearinghouse for uddannelsesforskning (i 2006) og et norsk Kunnskapssenter for utdanning (i 2013). Det danske clearinghouse vil ifølge deres første leder bidra til «beviselig praksis og politikk på uddannelsesområdet». I Norge vil Kunnskapssenteret blant annet formidle forskning om «hva som virker og ikke virker kvalitetsfremmende i skole og opplæring». Målsetningen til senteret er å bidra aktivt til kunnskapsbasert «politikkutforming, forvalting og praksis». Praksis og politikk på utdannelsesområdet skal være evidensbasert.

What works-tenkningen har også møtt skarp kritikk. Kritikerne hevder at for at snakket om effektiv undervisning skal ha mening, må det ses i sammenheng med de formål som er satt for utdannelsen. Det vil si at verken politikk eller forskning kan se bort fra at en utdannelse er normativ for å gi mening. Utdannelsens normative aspekt krever analyse og refleksjon uttrykt $i$ åpen debatt.

Til dette temanummeret ønsket vi artikler med ulike innfallsvinkler, perspektiver og metoder - og gjerne frigjørende tanker. Det har vi fått. Nordisk tidsskrift for pedagogikk og kritikk anser det som en sentral oppgave å bidra til at den pågående samtalen om skole, utdanning og danning skjerpes - politisk, historisk, kulturelt. Når den pedagogiske forskningen blir mer og mer spesialisert er det en fare for at de pedagogiske diskusjonene også blir smalere, både når det gjelder hva vi snakker om og hvem vi snakker med. Vi oppmuntrer til det Michael Oakshott kalte the conversation of mankind, altså en samtale om hvem vi er og hva vi utdanner for. Konkret oppmuntrer vi til slike samtaler ved å publisere Jacob Klitmøller og Dion Sommers tekst «Turboladet globalisering og den fremtidsparate skole» som en target article. Det innebærer at vi har invitert forskere fra ulike land i Norden - spesialister på 
M. Øksnes et al.

ulike felt - til å kommentere artikkelen og forfatterne til å svare. Vi oppfordrer våre lesere til å fortsette diskusjonen om denne artikkelen og de andre artiklene som publiseres i dette temanummeret.

Trondheim og Oslo, 11.11.16

Maria Øksnes, Einar Sundsdal og Lars Løvlie

Redaktører 